\title{
Impact of Blighia sapida (k. Koenig) aril consumption on viscera and their functionalities
}

\author{
Ouattara Howele $^{1 *}$, Kamagate Soualio ${ }^{1}$, Kokore Angoua Baudoin ${ }^{1}$, \\ Kati-Coulibaly Seraphin ${ }^{2}$ \\ ${ }^{1}$ Peleforo Gon Coulibaly University, Cote d'Ivoire \\ ${ }^{2}$ University Felix Houphouet-Boigny Cocody-Abidjan, Cote d'Ivoire \\ *Corresponding author: Ouattara Howele: ouattarahowele@gmail.com
}

\section{OPEN ACCESS}

Citation: Howele O., Soualio K., Baudoin K.A., Seraphin K. (2019) Impact of Blighia sapida (k. Koenig) aril consumption on viscera and their functionalities. Open Science Journal 4(1)

Received: 19 th $^{\text {th }}$ March 2019

Accepted: $12^{\text {th }}$ April 2019

Published: $13^{\text {th }}$ June 2019

Copyright: (C) 2019 This is an open access article under the terms of the Creative Commons

Attribution License, which permits unrestricted use, distribution, and reproduction in any medium, provided the original author and source are credited.

Funding: The author(s) received no specific funding for this work

Competing Interests: The author have declared that no competing interests exists.

\section{Abstract:}

The aim of this study was to understand the effects of Blighia sapida aril consumption on viscera and their functionalities. For this instance, quantities of arils were cooked $(500 \mathrm{~g} / \mathrm{l})$ and lyophilize. Six homogeneous groups of young rats were fed ad libitum with six different diets which can be distinguished by the level of Blighia sapida aril powder put in the diet formulate. There were control diet $(0 \%$ Blighia sapida arils powder), Bs1 (6.25\% Blighia sapida arils powder), Bs2 (12.5\% Blighia sapida arils powder), Bs3 (25\% Blighia sapida arils powder), Bs4 (50\% Blighia sapida arils powder) and Bs5 (75\% Blighia sapida arils powder). At the end of the experimentation, blood samples were collected and were used for analyses of plasmatic bilirubin content. After sacrificed the experimental rats, stomach, liver, kidney, heart and lung were removed and weighted. These organs were processed for histopathological studies. There were no different variation $(p>0.05)$ of bilirubin content between rats which received control diet and those which received the experimental diets. Organs weight of rats fed with diets Bs1, Bs2 and diet Bs3 were not globally different $(\mathrm{p}>0.05)$ compare to those of the control diet while organs weight of rats fed with diets Bs4 and Bs5 were globally reduced $(\mathrm{p}<0.05)$. No pathologies on viscera were observed when Blighia sapida aril powder is consumed with moderation (under a value of $50 \%$ of nutrition value need). But, when consumed with exaggeration it provokes lipid nephrosis lesions on kidneys cells and necrosis on hepatic parenchyma. We can notice that Blighia sapida aril is rich nutritiously but it must be consumed with moderation in order to avoid pathologies on viscera. 
Keywords: Blighia sapida aril, diet, rats, viscera weight and functionalities

\section{Introduction}

Previous studies showed that Blighia sapida arils consumption at degree close to $50 \%$ of the daily nutritional intake did not have any impact on the growth of rats which consumed these diets [1]. In fact coat quality, the well-being and the lipids parameters of the rats were normal in comparison to that of rats which consumed a usual control diet call AIN-93G [2]. Also, bones formations and their functionalities were not perturbed [3]. These showed that diets formulated were rich nutritiously. On the other hand, rats fed with diets containing Blighia sapida aril powder exceeding $50 \%$ of the daily nutritional intake showed growth retardation, bone mass acquiring retardation but, they didn't show disruptions in the functionalities of bones. What about the impact of Blighia sapida (k. Koenig) aril consumption on viscera and their functionalities? Results which will be presenting in this study talking about the effects Blighia sapida (k. Koenig) aril level in diet on viscera (brain, heart, lung, stomach, liver, spleen and kidney) and their functionalities.

\section{Material and methods}

\section{Material}

\section{Plant material}

In Côte d'Ivoire, Blighia sapida is planted in Katiola region (North Côte d'Ivoire). Arils are consumed in this region by people. Arils used for the experimentation were brought from Katiola in the period of March, April, and May when they are more available. They were spread on polythene paper and exposed to sunlight to dry for two weeks, six hours a day. In the night, they were kept on the plastic and put in a house at room temperature $\left(25^{\circ} \mathrm{C}-30^{\circ} \mathrm{C}\right)$. After the drying process of the fresh aril, the dried arils were kept in plastic bags and sent to Abidjan (South of Côte d'Ivoire).

\footnotetext{
Animals

36 young albino Wistar rats weighing (49-75 g) were used. They were bred in the animal house of the Unity of formation and Research Biosciences of the University Félix HOUPHOUËT-BOIGNY of Abidjan (Côte d'Ivoire). During the breeding, rats were fed with an ailment made by a society in Côte d'Ivoire call IVOGRAIN which is specialized in mass production of livestock ailment. This ailment is making up by crud protein matter (15\%), crud fat matter $(3.5 \%)$, cellulose matter $(12 \%)$, mineral matter $(9 \%)$, calcium $(1 \%)$, phosphorus $(0.9$ $\%)$, sodium $(0.3 \%)$, vitamin A (15000 ui $/ \mathrm{kg})$, vitamin D3 (3000 ui $/ \mathrm{kg})$, vitamin $\mathrm{E}(10 \mathrm{mg} / \mathrm{kg})$.
} 


\section{Methods}

\section{Preparation of the arils}

At Abidjan, the dry arils were crushed with a mortar. Each time $500 \mathrm{~g}$ of Blighia sapida arils powder were cooked using a gas stove in one liter of water (500 g/l) during two hours. Arils pasta obtains were lyophilized. The powder obtain was used to formulate five kind of experimental diet call Bs1, Bs2, Bs3, Bs4 and Bs5. Previously, a control diet was prepared. The composition of the control diet was similar to that recommend to scientist by the American Institute of Nutrition for rapid Growth (AIN-93G) when they want to make experience with animals particularly rats [2].

\section{Difference between experimental diets}

In experimental diets, a part of the control diet was substituted by Blighia sapida arils powder.

The degree of substitution was respectively $6.5 \%, 12.5 \%, 25 \%, 50 \%$ and 75 $\%$ for Bs1, Bs2, Bs3, Bs4 and Bs5.

\section{Experimentation}

At the beginning of the experimentation, the animals were grouped to form six homogeneous young groups of rats. They were put individually in metabolic cages and maintained under standard laboratory conditions (temperature $25 \pm 2^{\circ} \mathrm{C}$ ) with dark and light cycle $(12 \mathrm{~h} / 12 \mathrm{~h})$. In the metabolic cages, rats were acclimatized to this condition and fed with the control diet five days before the commencement of the experiment. After that, they were fed ad libitum with the different diets (control diet, Bs1, Bs2, Bs3, Bs4 and Bs5) according to the different group of animals during 28 days.

\section{Biochemical parameters}

At the end of the experimentation, blood sample was collected at the vena cava level of all animal and put in individually vacuum valve. These blood samples were used for analyses of the plasmatic bilirubin (total bilirubin and conjugated bilirubin) content using an automatic chemistry analyzer (Hitachi model 902, Roche).

\section{Organ removal}

Animals were sacrificed and heart, kidney, liver, lung, spleen and stomach were delicately removed and their weight was determined.

\section{Histopathology}

After that, liver, kidney and heart of each animal were put together in individually tube containing $10 \%$ buffered formalin solution. The organs were processed for histopathological studies [4, 5]. These studies were necessitated appropriate histological technologies. Liver histopathological study of each animal was performed using three kinds of coloration, hemotoxylin-eosin coloration, trichome de masson coloration and perls coloration, while the histopathological study of heart and kidney was performed using only hemotoxylin-eosin coloration. Tissues obtain at the finish were examined by a pathologist. 


\section{Statistical analyses}

The experimental results were expressed as the mean \pm S.E.M. Data were assessed by the method of analysis of ANOVA followed by Dunnett test [6, 7]. p value of $<0.05$ was considered as statistically significant.

\section{Results}

\section{Effect of Blighia sapida aril powder level in diets on plasmatic bilirubin}

Total bilirubin level observe were $11.17 \pm 0.75 \mathrm{mg} / \mathrm{ml}$ for rats fed with Bs1, $11.00 \pm 1.67 \mathrm{mg} / \mathrm{ml}$ for rats fed with diet Bs2, $12.05 \pm 1.41 \mathrm{mg} / \mathrm{ml}$ for rats fed with diet Bs3, $12.33 \pm 1.37 \mathrm{mg} / \mathrm{ml}$ for rats fed with diet Bs4 and $11.25 \pm 0.96 \mathrm{mg} / \mathrm{ml}$ for rats fed with diet Bs5. These value are not significantly different $(\mathrm{p}>0.05)$ to that obtain on rats fed with control diet $(12.17 \pm 0.75 \mathrm{mg} / \mathrm{ml})$. These results are shown on figure 1.

Concerning the conjugated bilirubin, values obtain were $5.50 \pm 0.55 \mathrm{mg} / \mathrm{ml}$ for control group of rats, $6.33 \pm 1.37 \mathrm{mg} / \mathrm{ml}$ for group of rats fed with diet Bs1, $6.00 \pm 1.41 \mathrm{mg} / \mathrm{ml}$ for group of rats fed with diet Bs2, $5.83 \pm 1.47 \mathrm{mg} / \mathrm{ml}$ for group of rats fed with diet Bs3, $7.00 \pm 1.41 \mathrm{mg} / \mathrm{ml}$ for group of rats fed with diet Bs4 and $6.00 \pm 0.82 \mathrm{mg} / \mathrm{ml}$ for group of rats fed with diet Bs5. There were no significant variation $(\mathrm{p}>0.05)$ between experimental values and that of the control one. These results are shown on Figure 1.

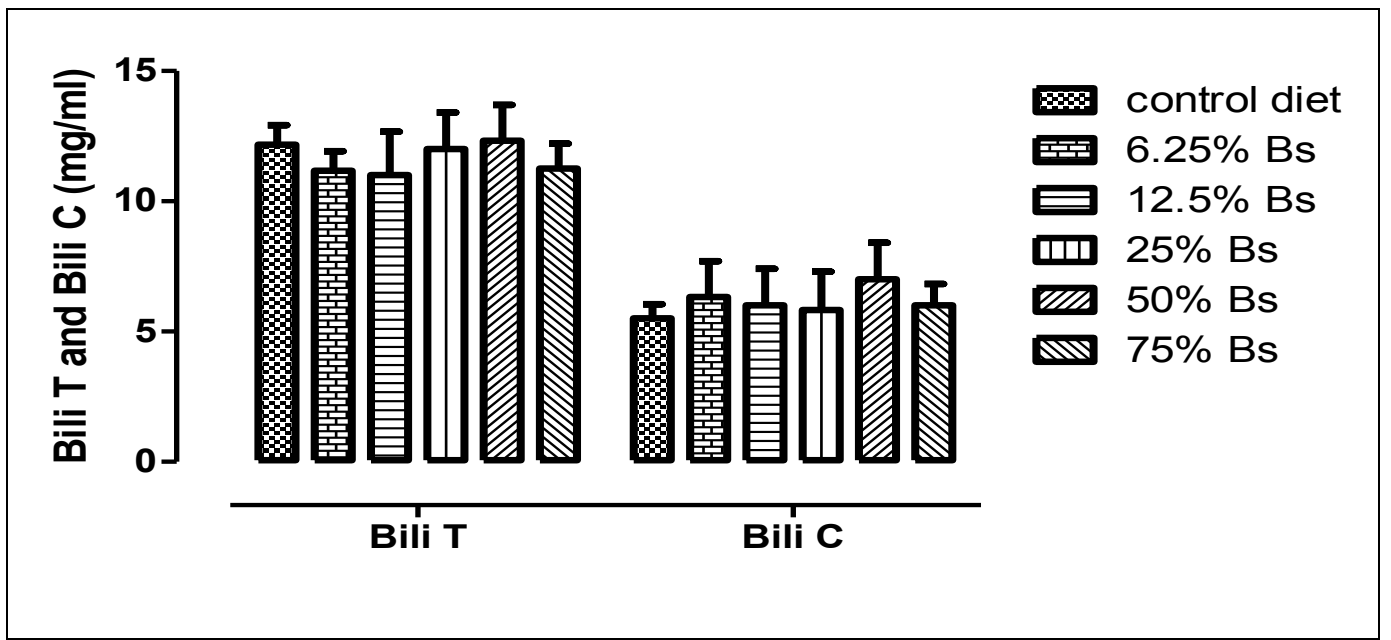

Figure 1: Effect of Blighia sapida aril powder level in diets on plasmatic bilirubin

(*) $\mathrm{p}<0.05$ : significant variation; Bili $\mathrm{T}$ : total bilirubin ; Bili $\mathrm{C}$ : conjugated bilirubin. 


\section{Effect of Blighia sapida aril powder level in diets on viscera weight.}

Rats fed with diets containing $6.25 \%, 12.50 \%$ and $25 \%$ of Blighia sapida aril powder had liver, kidneys, stomach, lung and heart weight which were not different $(\mathrm{p}>0.05)$ compare respectively to those of the control diet. On the other hand, on rats fed with diets containing $50 \%$ and $75 \%$ of Blighia sapida aril powder, it was noticed a significant diminution $(\mathrm{p}<0.05)$ of heart weight and lung weight and a high significant diminution $(\mathrm{p}<0.01)$ of stomach weight, kidneys weight and liver weight compare respectively to those of the control diet (Fig 2, Fig 3, Fig 4, Fig 5 and Fig 6).

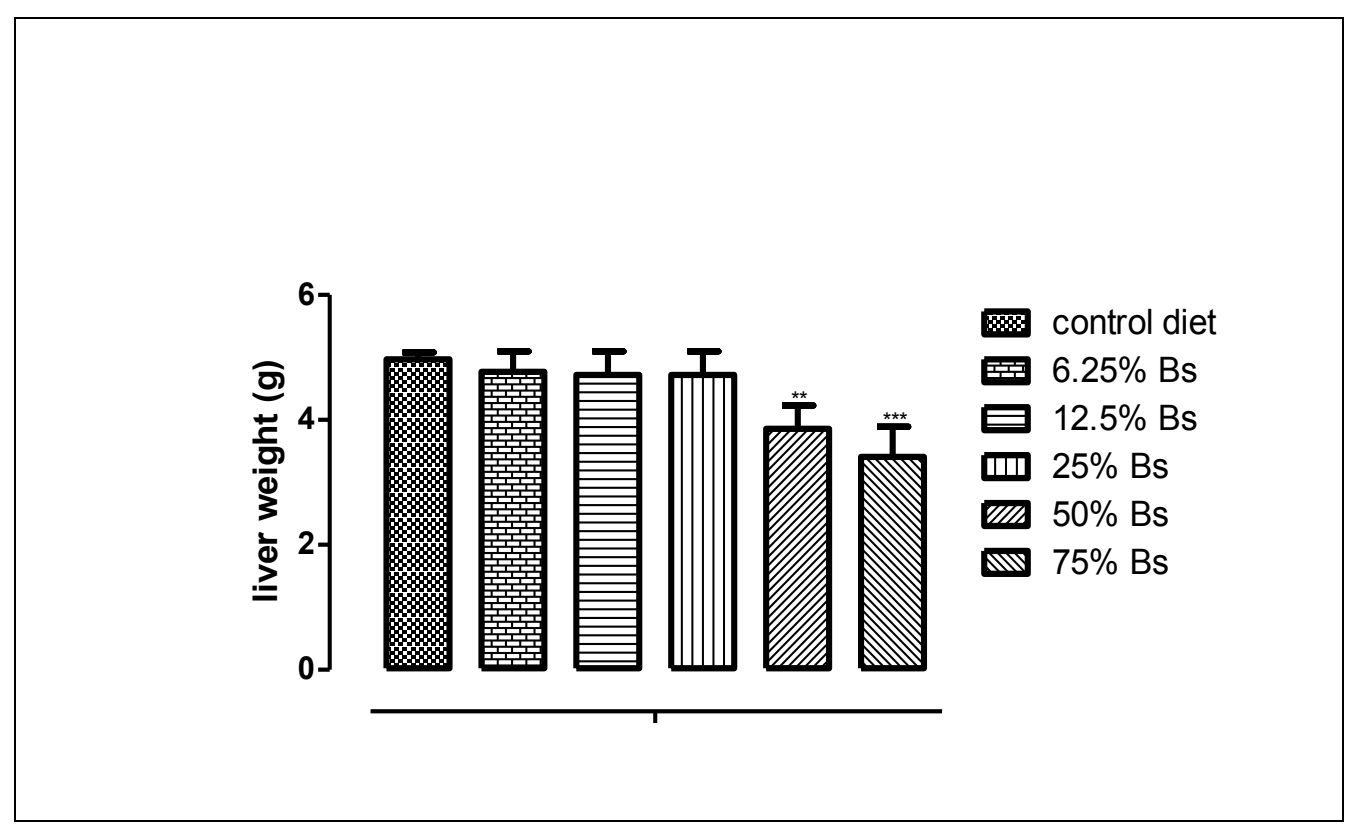

Figure 2: Effect of Blighia sapida aril powder level in diets on liver weight

$\left(^{*}\right) \mathrm{p}<0.05$ : significant variation; $(* *) \mathrm{p}<0.01$ : high significant variation;

$(* * *) \mathrm{p}<0.001$ : very high significant variation 


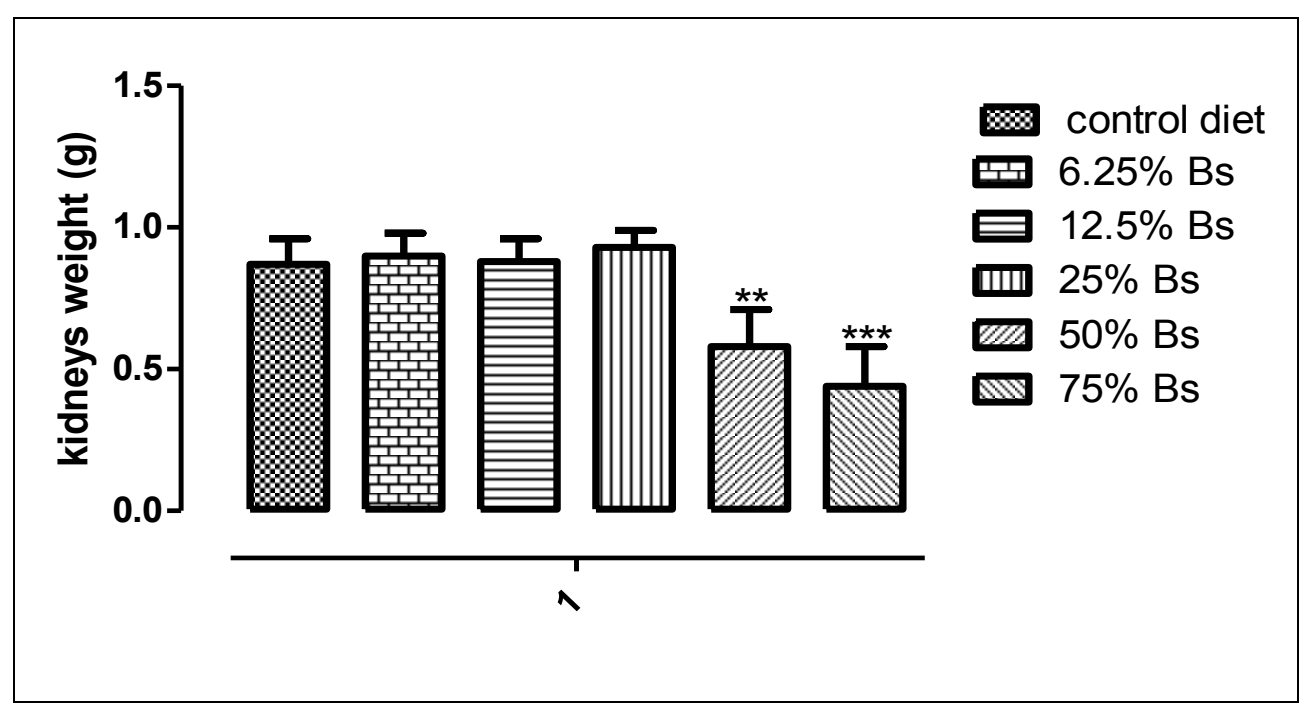

Figure 3: Effect of Blighia sapida aril powder level in diets on kidneys weight $(*) \mathrm{p}<0.05$ : significant variation; $(* *) \mathrm{p}<0.01$ : high significant variation; $(* * *) \mathrm{p}<0.001$ : very high significant variation

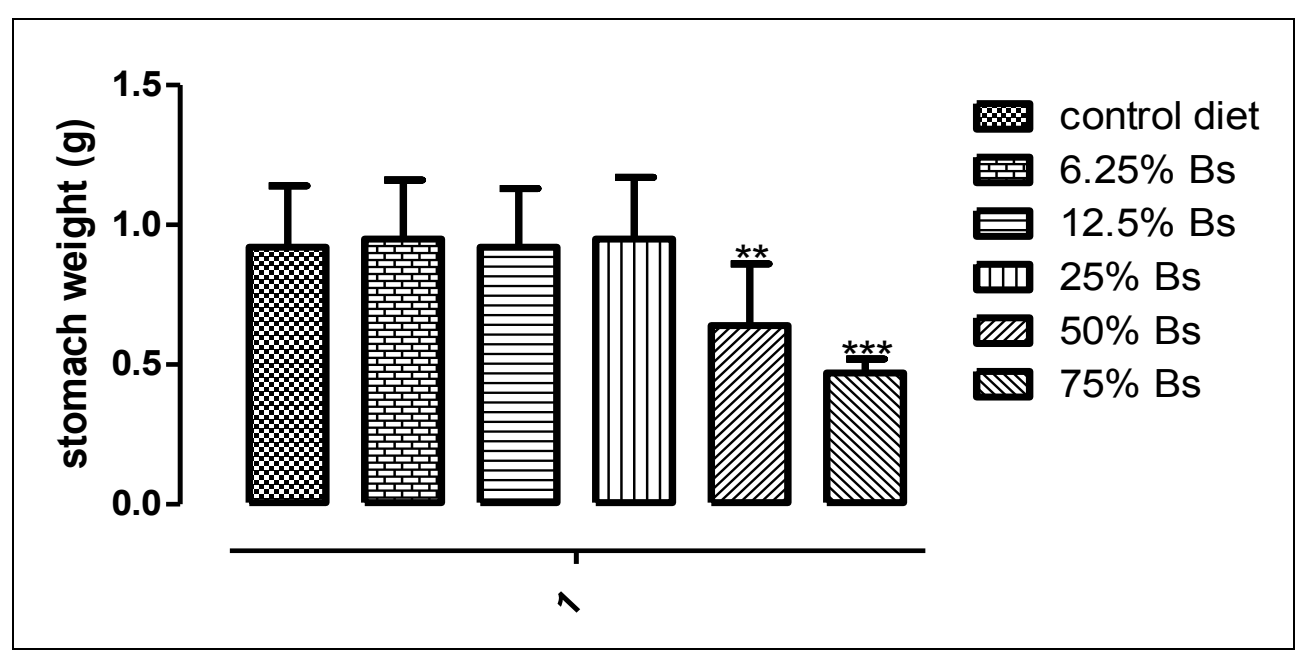

Figure 4: Effect of Blighia sapida aril powder level in diets on stomach weight $(*) \mathrm{p}<0.05$ : significant variation; $(* *) \mathrm{p}<0.01$ : high significant variation; $(* * *) \mathrm{p}<0.001$ : very high significant variation 


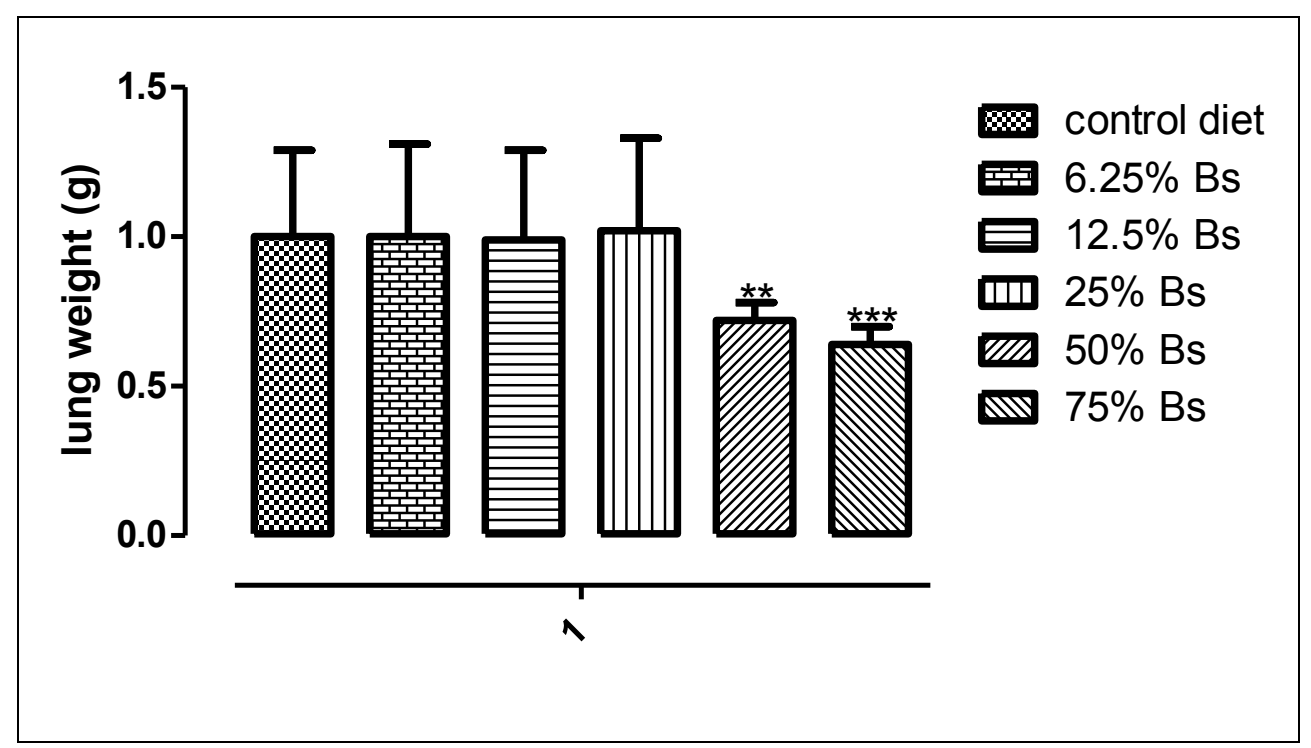

Figure 5: Effect of Blighia sapida aril powder level in diets on lung weight $(*) \mathrm{p}<0.05$ : significant variation; $(* *) \mathrm{p}<0.01$ : high significant variation; $(* * *) \mathrm{p}<0.001$ : very high significant variation

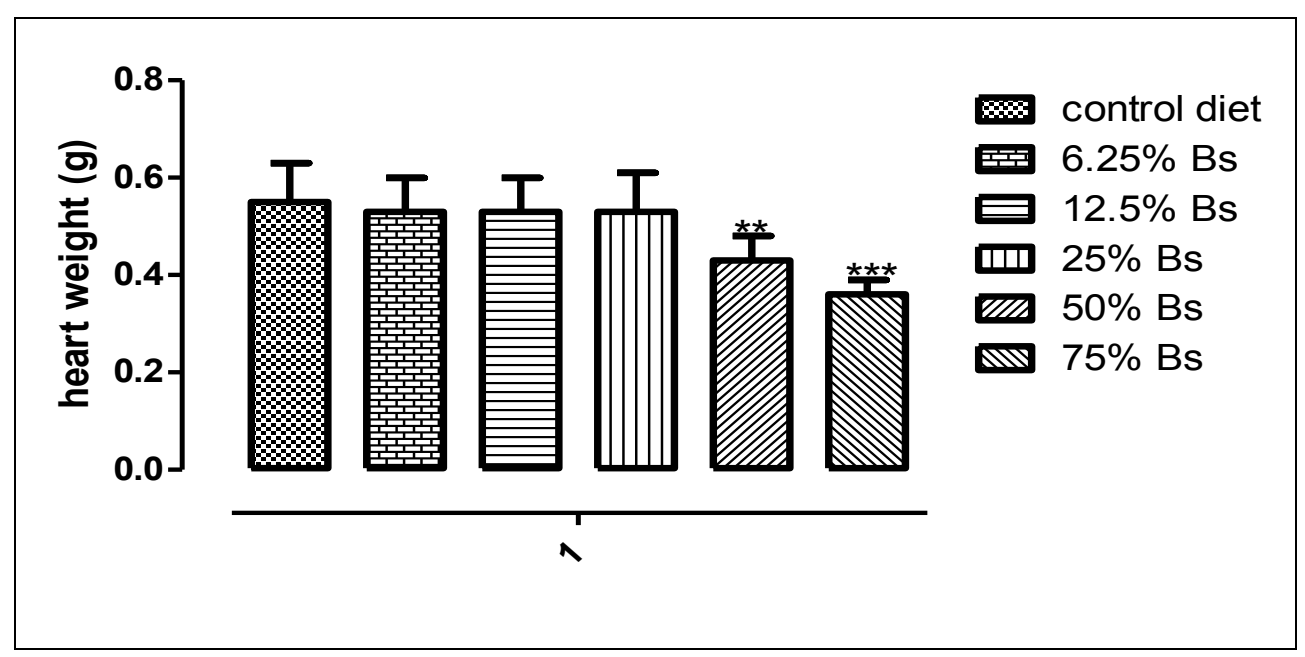

Figure 6: Effect of Blighia sapida aril powder level in diets on heart weight $(*) \mathrm{p}<0.05$ : significant variation; $(* *) \mathrm{p}<0.01$ : high significant variation; $(* * *) \mathrm{p}<0.001$ : very high significant variation 


\section{Histopathological studies of liver, kidneys and heart}

\section{Livers colored with hematoxylin-eosin coloration}

After being colored with hematoxylin-eosin coloration, histological section of livers of rats fed with diets containing 6.25\%, $12.50 \%$ and $25 \%$ of Blighia sapida aril powder showed that hepatic parenchyma were not subjected to any structural modification in the same way as rats fed with the control diet (Fig 7 A). On the other hand, on histological section of livers of rats fed with diets containing $50 \%$ and $75 \%$ of Blighia sapida aril powder, it was observed necrosis on hepatic parenchyma (Fig 7 B).
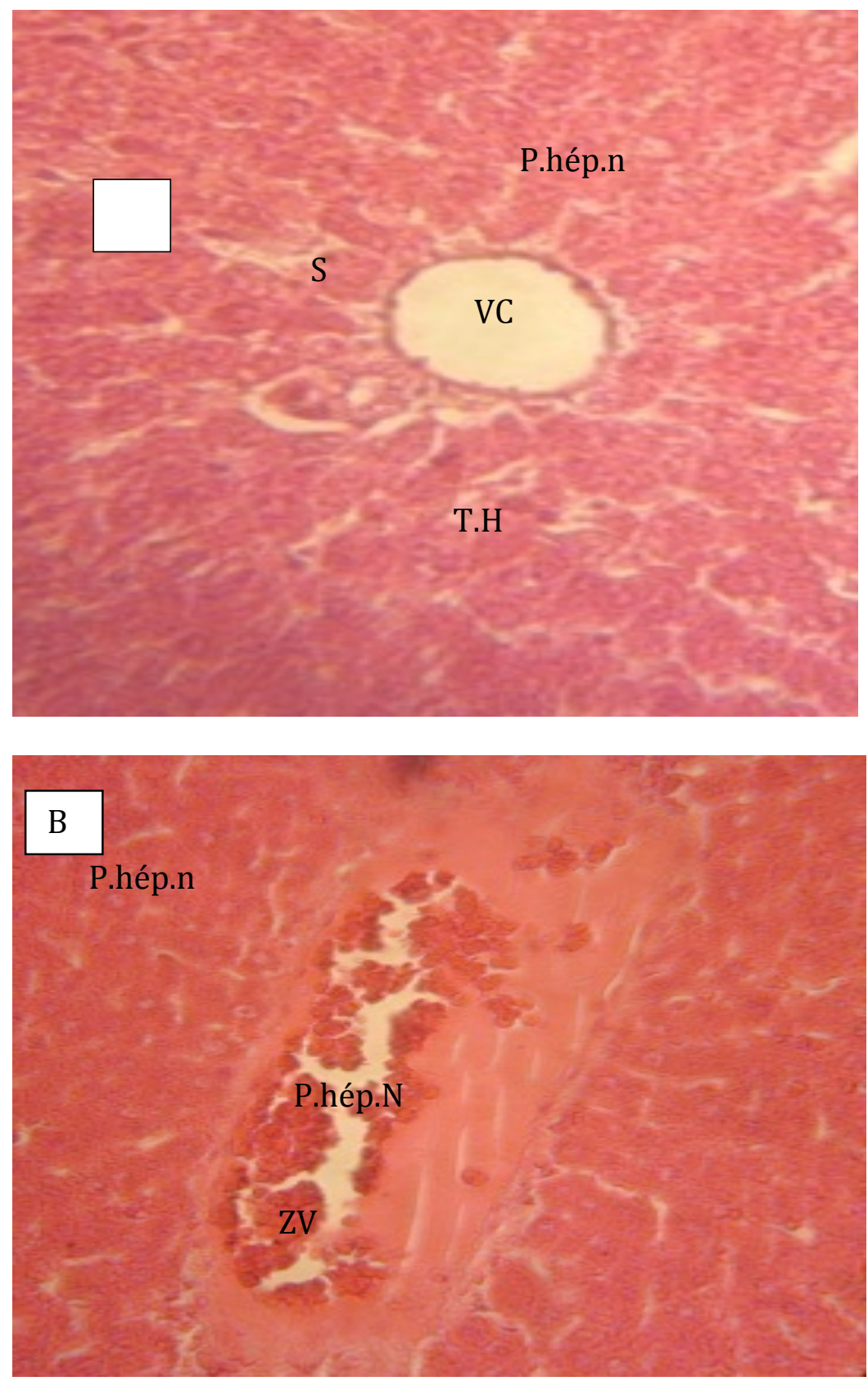

Figure 7: Histological section of rats liver fed with diets containing proportion of Blighia sapida aril powder 
A: Diets containing lower level of Blighia sapida aril powder $(0 \% ; 6.25 \%$; $12.5 \% ; 25 \%$ ): Hepatic parenchyma is not subjected to structural modification;

B: Diets containing high level of Blighia sapida aril powder $(50 \% ; 75 \%)$ : It is observed necrosis on hepatic parenchyma.

Annotation

P.hép.n : normal hepatic parenchyma ; P.hép.N : necrosis hepatic parenchyma $\mathrm{S}$ : sinusoid ; VC : center lubular vena ; $\mathrm{ZV}$ : vacuolar zone ; $\mathrm{TH}$ : Bay of hepatocyte

Coloration : hemotoxylin-eosin ; Magnification : $\times 400$

\section{Kidneys colored with hematoxylin-eosin coloration}

After being colored with hematoxylin-eosin coloration, histological section of kidneys of rats fed with diets containing $6.25 \%, 12.50 \%$ and $25 \%$ of Blighia sapida aril powder showed that there were no injuries due to necrosis on kidneys tissues as well as that of the rats who consumed the control diet (Fig 8 A). On the other hand, on histological section of kidneys of rats fed with diets containing $50 \%$ and $75 \%$ of Blighia sapida aril powder it was observed lipid nephrosis lesions on kidneys cells. These lesions were materialized by the presence of vacuole (Fig $8 \mathrm{~B})$.

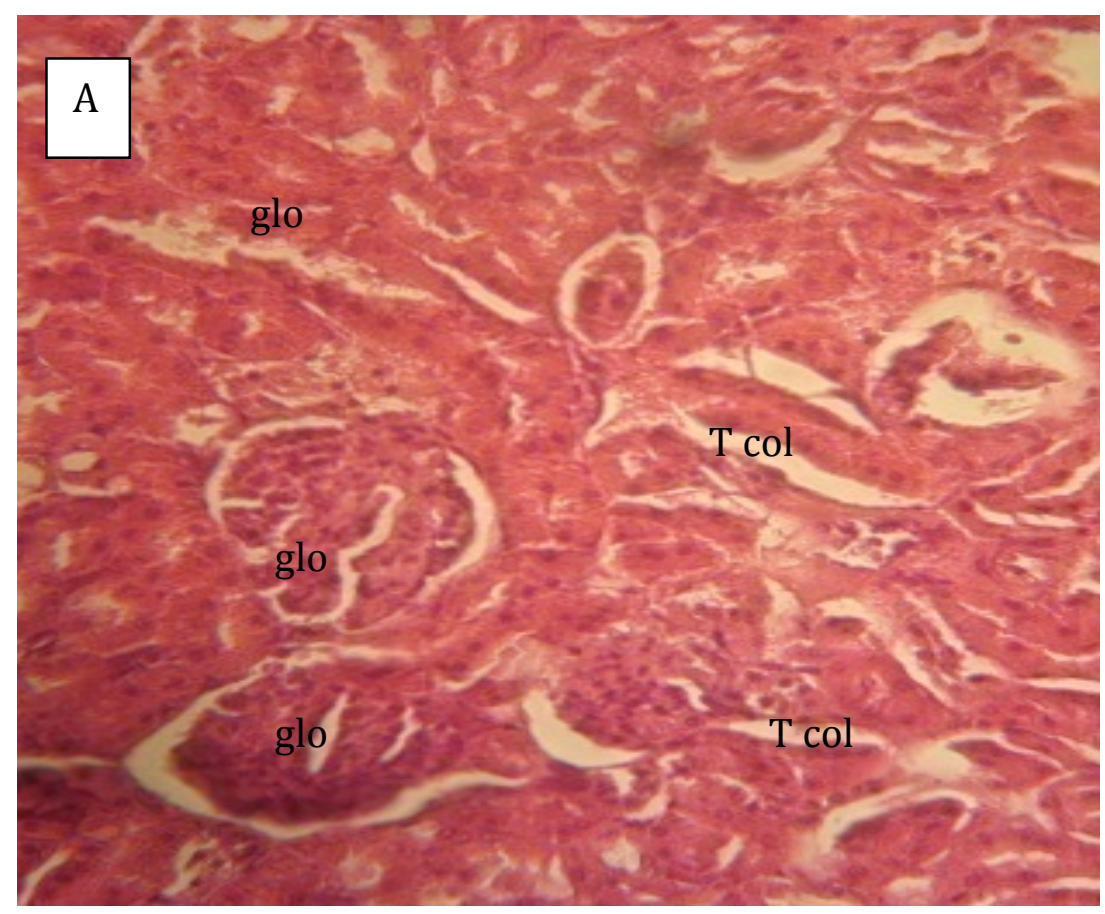




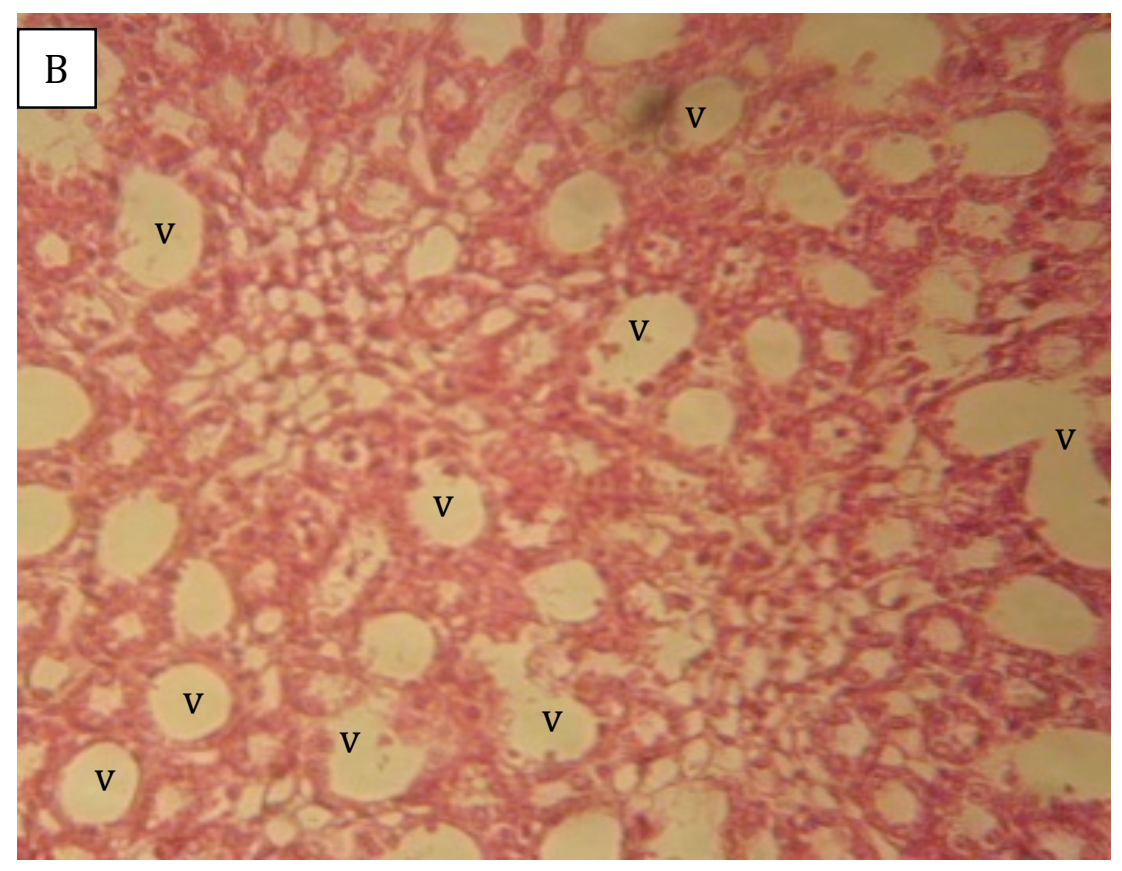

Figure 8: Histological section of rats kidney fed with diets containing proportion of Blighia sapida aril powder A: Diets containing lower level of Blighia sapida aril powder $(0 \% ; 6.25 \% ; 12.5 \% ; 25 \%)$ : kidneys tissues are not subjected to abnormalities. Glomeruli are visible;

B: Diets containing high level of Blighia sapida aril powder (50\%; $75 \%$ ): It is observed lipid nephrosis lesions on kidneys cells. These lesions are materialized by the presence of vacuole.

Annotation: glo: glomerulus; Tcol: collector tubule; V: vacuole.

Coloration : hemotoxylin-eosin ; Magnification : $\times 400$

\section{Others histopathological studies}

The hematoxylin-eosin coloration didn't reveal pathologic modification on heart tissue of each animal whatever the diets consumed.

The others coloration, Ttrichome de masson and perls, made on livers tissues of each animal didn't also reveal pathologic modification whatever the diets consumed.

\section{Discussion}

It is known that bilirubin is not a very much important indicator in detecting hepatic diseases but it gives an idea on the global functioning of liver whatever the disease $[8,9,10]$. In our study no significant variation $(\mathrm{p}>0.05)$ of total bilirubin and conjugated bilirubin were noticed. This could then suggest that liver of animals was not subjected to any disease. So, it was important to make anatomopathological studies.

On rats fed with the different diets, Perls coloration didn't reveal ferric deposit in the hepatic tissue. This testify that there isn't toxic hemolysis due to the presence of molecule endowed with toxic effect in the different diets whatever 
the level of Blighia sapida aril powder in diet which was consumed by rats. In the same way Trichome de masson coloration didn't permit to observe abnormality on hepatic tissue. These absence of abnormalities showed that the different diets consumed by rats didn't provoke structural modification such as fibrosis on the hepatic tissue. Nevertheless hematoxylin and eosin coloration permit to detect on hepatocyte of rats who consumed diets containing $50 \%$ or $75 \%$ of Blighia sapida aril powder necrosis on hepatocyte and on kidney cells lipid nephrosis. This could indicate that consumption of Blighia sapida aril at degree neighboring or higher than $50 \%$ is the cause of hepatic and kidney attack. These attacks induced dysfunction of these organs (liver and kidneys).

\section{Conclusion}

Anatomopathological results are agree with the previous studies in the same that Blighia sapida aril powder could be consumed up to a value of $50 \%$ of the entire need of the organism with no trouble. Beyond this value its consumption provokes hepatic and kidneys disorders.

\section{Acknowledgment}

The author, OUATTARA Howélé, is grateful to the Unity of formation and Research (UFR) biosciences of University of Félix HOUPHOUËT-BOIGNY for permitting us to work in their laboratories.

\section{References:}

[1] Ouattara, H., Meité, A., Kouamé, P., Kati-Coulibaly, S., 2016. Impact of Blighia sapida (k. Koenig) aril powder level in diet on the growth and the well-being of albino Wistar rats. Afr. J. Food Sci, 10(9) : 164-171.

[2] Reeves, P. G., Nelsen F. H., Fahey G. C. J., 1993. Purified diets for laboratory rodents: final report of the American Institute of Nutrition ad hoc writing committee on the reformulation of the AIN-76A rodent diet. J. Nutr, 123: 1939-1951.

[3] Ouattara, H., Meité, A., Soro, S., Kati-Coulibaly, S., 2016. Blighia sapida Aril Consumption at Degree Neighboring $50 \%$ do not Affect Bone Growth of Rats, from $50 \%$, Bone growth is Negatively Affected. Indian J Nutri, 3(2): 144.

[4] Hawk, P. B., 1965. Urine qualitative analysis. In Hawk's Physiology Chemistry. Tata McGraw Hill Book, Company Ltd., New Delhi, India. Edited by Oser, B.L. 14th edition, 1032-1034.

[5] Andre, J-M., Catala M., Merene, J.J., Escudier, E. , Katsanis,G., Poirier, J., 2008. Histologie : les tissus ; matériel et méthodes de l'histologie médicale. PAES, 2-27.

[6] Ostle, B, 1966. Statistics in Research. Iowa state university press, Iowa, USA, 310-361.

[7] Woolson R. F, 1987. Statistical methods for the Analysis of Biomedical Data. John Wiley and Sons Inc., New York.

[8]. Neuberger, J., 1991. Primary biliary cirrhosis. Gut., 32 (suppl.9), p 573.

[9]. Baufrere B., (1993). Evaluation du métabolisme protéique. In traité de Nutrition Pédiatrique.

[10]. Williams S. R., (1994). Essentials of Nutrition and Diet Therapy. 6th ed. Mosby, 521p 